\title{
The External Auditor's Opinions and The Stakeholders' Purposes: An Empirical Analysis in Sri Lanka
}

\author{
S.R.M. Wickramasingha ${ }^{1}$ and K.G.M. Nanayakkara² \\ ${ }^{1}$ Rathnayake T.A \& Company, Chartered Accountants, Work Place Address: 17, Rodney \\ Street, Off Road, Colombo 08, Sri Lanka \\ wickramasinghasrm@gmail.com
}

${ }^{2}$ Department of Commerce and Financial Management, Faculty of Commerce and Management Studies, University of Kelaniya, Sri Lanka madurikan@gmail.com

\begin{abstract}
This paper specially investigate the Sri Lankan audit opinions and its' effect to the investors' decision making. It has been conducted the market-based model with a sample of thirty one (31) listed manufacturing companies on the Colombo Stock Exchange; the dependent variable "Stock Return" serve as proxy for Investors' Decisions and independent variables are "Audit Opinions" published in Sri Lanka. The study use Anova test for the study. This research study's final consequence is robust the notion of the audit opinions are not informative value to the investors' decisions.
\end{abstract}

Keywords: Auditing, Audit Opinions, Stakeholder's Purposes, Capital Gain Yield, Colombo Stock Exchange

\section{Introduction}

According to the archival studies the main role of the financial statement auditing is promulgation the appropriate audit opinion. Financial statement auditing is identified as a good research area by the scholars, since it has unconvincing and denial in literatures in accordance with prior literature exposures; For instance, to the best of prior scholars' investigations report different conclusions as different country wise as well as different regimes. As an example, in the United Kingdom (UK) position audit may help for the stakeholders make better decisions (Power, 1994). The UK has a broader view about the auditing, because they usually audit the financial statement's reliability as well as concerning 
the economic efficiency (Palepu, 2008). According to the Palepu \& Healy (2008) in the United States (US) situation has been expressed steadily progression the worth of the audits to the investors. Additionally, in USA different audit opinions presents different market reactions to the audit opinions (Dopuch et al, 1987). In China, the results were presented by Chen et al (2000) that the audit opinions have information content for the investors' decisions. When Spanish market was investigated by Martínez† et al (2004) found the modified audit opinions has not any information content to the investors.

As the results of the above literatures have divulged the various countries have different conclusions as well as the literatures have been declared the various result regarding same country investigations also; For example, the US literatures said that the results of the relationship between audit opinions and the investors or stock markets are minor or inconclusive (Mutchler, 1985: Dodd et al., 1984: Elliott, 1982). Otherwise the audit opinions have information value (Chen \& Church, 1996: Jones, 1996). Different audit options have different reactions with financial and market variables (Dopuch, 1987). And also same audit opinion has a different investigation results, for instance; when consider about going concern audit opinion (GCAO), it has disparate investigations' result as reviewing; such Mutchler (1985) said that the investigation provides little evidence for the GCAOs about information content and same as Dodd et al. (1984) was presented the result. The information content of "Subject to" audit opinions including going concern audit opinions that disclosed the going concern circumstances in the firm is inconclusive (Elliott, 1982). The GCAO has information value (Chen \& Church, 1996: Jones, 1996).Finally concerned the all literatures' finalized outcome here concludes the results are inconclusive and have the contradiction in literatures, therefore it guides and promote to further investigation. According to the above descriptions it is proven the importance of this study and this investigation provides 
new knowledge to the existing body of knowledge such evidence regarding investors' decisions on all audit opinions in Sri Lanka.

In this investigation researchers have found out the effect of the each audit opinion to the investors' decisions (CGY) in Sri Lankan context. There are mainly three audit opinions as Unmodified Audit Opinion (UMAO), Modified Audit Opinion (MAO) and Unmodified Audit Opinion with Emphasis of Matter Paragraph (U-EMP). According to Sri Lanka Accounting and Auditing Standards act and the Auditing Standards, the responsibility of the auditor is to express an opinion on the preparation and presentation of the financial statements. The main purpose of this is to satisfy the referees of the financial statements about the true and fairness of them through an opinion from an independent party. However, the issue here is how far the users of the financial statements are considering the auditor's opinion in their decision making process. Hence, we thought to investigate this problem through this research study and we concentrate on the issue considering only the investors decision making. Therefore, the objective of this study is to determine the significance of external auditors' opinions on the firm Stakeholders' Purposes (Investors' Decisions).

In order to solve the problem highlighted, researchers applied the market based model (Craswell, 1985) with investigating all audit opinions publicizing widely in Sri Lanka and capital gain yield used as the dimension of the investors' decision making. Selected thirty one (31) manufacturing companies listed on Colombo stock exchange (CSE) as the real sample and this study based on secondary data. One way- Analysis of Variance (ANOVA) is used as the analysis method. This research study's final consequence is robust the notion of the audit opinions are not informative value to the investors' decisions.

The research study demonstrates as following sequences. The next section deals with the review of past studies in relating to external audit opinion and 
stakeholders decision making. The third part, methodology section, discusses the selected variables, data set, method and methodology. The fourth section presents the data analysis and finally the conclusion of the study is presented.

\section{Literature Review}

When carefully behold the earlier literatures, it reveals a controversial research gap in relation to UMAOs or Clean Audit Opinions (CAOs). Even though the past studies not directly investigate the problem with the CAOs they provide results that the CAOs are responding differently in contrast with the other audit opinions (Dopuch et al, 1987: Whittred, 1980: Carlson et al, 1998). In addition to that the responses are not found imposingly between the CAOs and the other audit opinions (Lin et al, 2003). As a whole, the CAOs have not information content or any market responses (Mutchler, 1985: Frost, 1991). However, according to Whittred, (1980): Firth, (1978) and Chen et al, (2000) CAOs have an informative value. CAOs are the positive sense indicators for the financial statement users (Chen\& Church, 1996: Carlson et al, 1998: Jones, 1996: Chen et al, 2000). In addition to that,

researchers like Lin et al, (2003) and Martínez† et al, (2004) has identified that CAOs have a little information content. The different investigations have interpreted different conclusions; from this utter the certain research gap and research problem that how the CAOs are influencing on the financial statement users' decision making or stock market.

The very important aid has been donated by the prior literature review in the certain gap identification of MAOs, The responses of the stock market or alert parties to the financial statements are varied by the nature of the MAOs (Dopuch $\mathrm{N}$ et al, 1987, Whittred, 1980, Firth, 1978 - Firth, A note on the impact of audit qualifications on lending and credit decisions, 1980, (Gul, 1990 and Lopez et al, 2009). Besides that the MAOs has expressed the Slight stock price responses or the little informative value (Dodd et al, 1984, Lin et al, 2003 and Craswell, 1985). 
Thenceforth reveal such, stock price responses have a negative relationship on MAOs (Dodd et al, 1984, Chen C. J et al, 2000, Frost, 1991 and Gul, 1990). There are studies that provide evidence of MAOs have informative values (Whittred, 1980, Choi \& Jeter, 1992, Chen et al, 2000, Menon \& Schwartz, 1987, Banks \& Kinney, 1982, Gul, 1990, Lopez et al, 2009 and Shelton \& Whittington, 2008). However, some investigations revealed that the MAOs are not information content or the informative value is unconvincing (Elliott, 1982, Martínez† et al, 2004, Frost, 1991, Dopuch N et al, 1986, Al-Thuneibat et al, 2008, Czernkowski et al, 2010, and Moradi et al, 2011). The research has provided lack of evidence about the information content or not much more important for the decision making (Craswell, 1985). Above research studies are contradicted and inconclusive; therefore the research gap has been displayed by the prior results of the studies besides it is emerging a research problem that how the MAOs are affecting on the decisions of the users of the financial statements.

At the very beginning looked up the archival data obviously assist to realize the certain research gap should be the most complete on the U-EMP, In accordance with the interpreted results have expose to view that the audit opinions discussed undergoing concern circumstances as well as special matter relating to the company are information content (Chen \& Church, 1996: Carlson et al, 1998:Jones, 1996: Chen et al, 2000, Taffler et al, 2004: Joe, 2003: Blay \& Geiger, 2001,Menon \& Williams, 2010, Kausar et al, 2009: O'Reilly, 2009: Schaub, 2006: Feldmann \& Read, 2013). The little evidences are presented by the investigations regarding the information content of the opinions relating to going concern (Dopuch et al, 1987: Mutchler, 1985: Joe, 2003: Ogneva \& Subramanyam, 2007: Herbohn et al, 2007). GCAOs' informative value is not appearing or inconclusive (Elliott, 1982). Long-run has the stock market responses towards GCAOs (Herbohn et al, 2007). The GCAOs are presented the manifest negative sense (Chen \& Church, 1996: Jones, 1996). Market variables react negatively on the 
going concern related audit opinions in short-run (Carlson et al, 1998). The responses are negative in long-run of the stock price return on audit opinions relating to the going concern (Taffler et al, 2004). Stock market variable is reacting negatively with the audit opinions are publicized by the auditors regarding going concern or materialized matter (Chen et al, 2000: Blay \& Geiger, 2001: Menon \& Williams, 2010). Especially interpret the evidence has not found any negative stock price responses on GCAOs (Ogneva \& Subramanyam, 2007). The results are interpreted as stock market underreacts to the GCAOs (Kausar et al, 2009). The additional proof is not derived from the investigation for the stock market underreacts to the GCAOs (Ogneva \& Subramanyam, 2007).

The study provides evidence that the stock market overreact on GCAOs (Schaub, 2006). The responses are varied on the GCAOs as the audit opinions' context (Menon \& Williams, 2010). Finally, the main conclusion has emerged from the most from previously mentioned archival studies the U-EMP such relating to GCAOs have informative value rather than the other types of audit opinions. Anyway, few in number of evidence promulgate the conflicting results. The curiosity be revealed on the above literatures that interpreted result will be same and robust the plentiful notion for the further investigation.

In accordance with all audit opinions and auditing, the distinctive interpretations are proven by the research's results and specialist guidance which different kinds of conclusions. It should be appeared the strong consequence which the auditing is valuable (Palepu \& Healy, 2008: Power, 1994), (İrem \& Deniz, 2012, Kelly \& Mohrweis, 1989, Gomez-Guillamon, 2003: Salehi \& Bizan, 2010). However, the somewhat studies expose, the research results provide little or lack of evidence about the audit opinions' information content (Craswell, 1985). And also dissimilar audit opinions are presenting different responses towards the decision making (Dopuch et al, 1987: Whittred, 1980). Additionally, the 
information content of audit opinions are not or inconclusive (Czernkowski et al, 2010: Roden \& Meador, 1980). In all appearance has been extract from the preceding literatures that the space between research results.

\section{Methodology}

This investigation is using the market-based research model; the main variables are conducted by the research which the stock price returns and the audit opinions respectively dependent variable and the independent variable. Data collected from secondary sources by using a selected sample during the time period of 2008-2013 and therein annual reports websites etc. Behalf of the stock price return this investigation use the $\mathrm{CGY}^{1}$.

\subsection{Conceptual Framework of the Study}

In order to answer the main research problem of the study, we have conceptualized the model as in Figure 01 below.

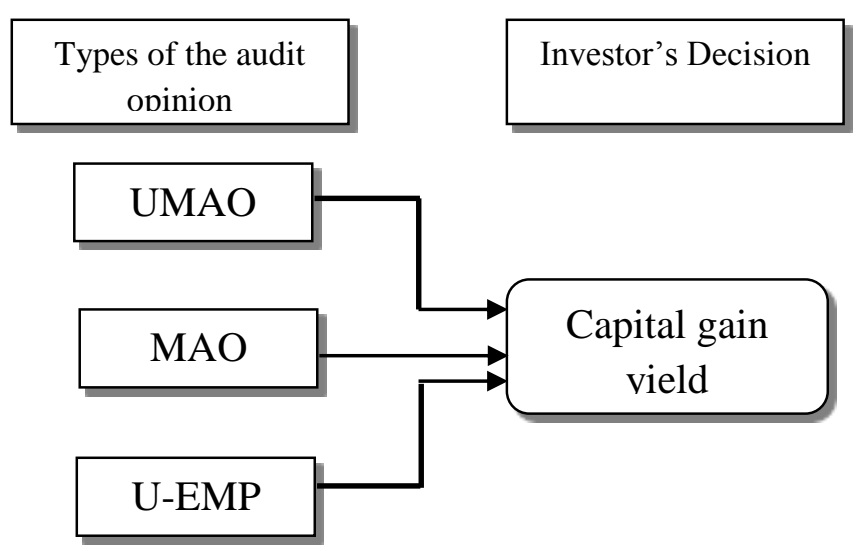

Figure 01: Conceptual Framework

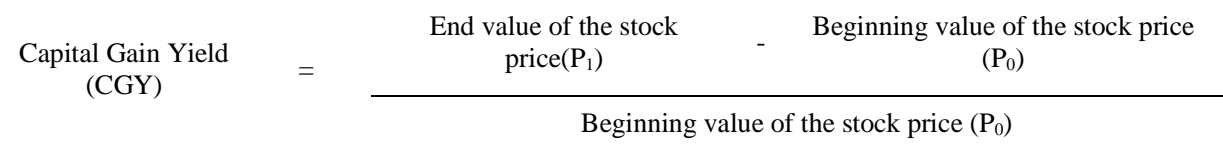


Table 01 depicts the way of sample selection and accordingly thirty one manufacturing companies listed in CSE has analyzed in our study.

\section{Table 01: Sample Selection}

\section{Description}

Sample

All manufacturing companies listed on the CSE begging the 2008 36

$\underline{\text { Deduct }}$

All rejected companies from the sample (subsequently, delisted companies are in the CSE)

Lack of data (companies beginning, after the first fiscal year)

Aggregate final sample

Source: Author

\section{Data analysis and Findings}

This section discusses the data analysis under the statistics, test of assumptions, estimated results and the findings. Table 2 shows the one way ANOVA test results in order to get the overall idea about the data set.

Table 02: One-way ANOVA Test Result

\begin{tabular}{lccccc}
\hline \multicolumn{6}{c}{ ANOVA } \\
& $\begin{array}{c}\text { Annual Stock Return } \\
\text { Sum of } \\
\text { Squares }\end{array}$ & Df & $\begin{array}{c}\text { Mean } \\
\text { Square }\end{array}$ & F & Sig. \\
& .001 & 2 & .001 & .165 & .848 \\
\hline $\begin{array}{l}\text { Between } \\
\text { Groups }\end{array}$ & .666 & 152 & .004 & & \\
\hline $\begin{array}{l}\text { Within } \\
\text { Groups }\end{array}$ & .668 & 154 & & & \\
\hline Total & & & & & \\
\hline
\end{tabular}

Source: Analyzed data 
The table of ANOVA is presenting the calculated statistics of the sample as a whole, not in a different manner, it provides the evidence of relationship about the all audit opinions and the CGY. The most consideration points are the significant value. ANOVA reveal the solution such, the difference was statistically not significant $(F(2,152)=0.165, p>0.05$. $)$, because the general theory that if the $\mathrm{P}$ value is above 0.05 , that is implied the relationship is statistically not significant; and also the $\mathrm{F}$ value are lower than one (1). The probability value represents the $\mathrm{P}$ value in the ANOVA table is $0.848(\mathrm{P}=0.848)$ and it is more than the tested significant level of the 0.05 ( $p>0.05$ ). One of the fundamental results emerges, thus derive clearly Accept the null hypothesis and reject the alternative hypothesis.

In here according to this investigations' hypothesis are accepted but the coming into view Type II error that the null hypothesis is incorrect but it should accept otherwise the testing unable to reject the null hypothesis. The observation has null hypothesis and alternative hypothesis as previously discussed, they can elaborate fundamentally it should be accepted the null hypothesis and reject the alternative hypothesis. The null hypothesis is as a whole there is a significant effect on CGY by influencing audit opinions. Ultimately the result reveals that the P value is 0.848 (examined significant level 0.05), it demonstrates the significant distinctive between handling groups. The table exhibit result of the present $P$ value is higher than the tested significant level value $(\mathrm{P}>0.05)$. Theory is accepting the null hypothesis such kind of circumstances. Therefore, it reveals that the null hypothesis of audit opinion have a significant impact on CGY but its need to pay careful attention about figure in the multiple comparison table.

By the result exporting ANOVA table the significant relationship also disclose between two dependent and independent variables. The $\mathrm{P}$ value is equal to the 0.848 , that as we mentioned above the tested significant level is $0.05(\mathrm{a}=$ 0.05 ) and the hold out result is calculated significant value is more than tested 
significant value $(0.848>0.05)$, it totally agree that there is no significant relationship between all audit opinions and the capital gain yield representing stock price return. The result obviously represent there is less relationship between audit opinions and the CGY, it derives audit opinions are not influenced to the stock price return, because the CGY is partially join with the stock price return. On the other hand basically, it deduced the audit opinion has not informative value and it's not providing any significant information towards investors to make investment decisions.

According to the Tukey HSD Post Hoc Test - multiple Comparisons in table 03 show the whole of probably pairs of comparisons here could be appeared. Not only has that it disclosed the $\mathrm{P}$ value for the every pair, and differences of means between each two pair. According to the multiple comparison table, it shows each difference which statistically significant or not.

In accordance with ANOVA table it should accept the null hypothesis and also reject the alternative one, but the problem is how the separate audit opinion means are different each other and what the value is. It can be tested by the Post hoc test in One-way ANOVA. Fundamental advertise should be concentrated to the 95\% confidence level and their lower bound and upper bound, thus the confidence intervals help to identify the distinguish between one by one pair of means.

Moreover, the significant level (testing 0.05 ) and the $\mathrm{P}$ value present the comparable explanation for the finding. Here the first column displays a one category and the subsequent column expresses the other categories compared to the previous one. There are three audit opinions and the sub groups compared to them. However here directly pay attention to the significant value of the table in each category; it seems the all the calculated significant value are strongly higher 
than the tested significant level of 0.05 . Therefore, the result can be derived as the each set of audit opinions are not significant with the other one.

It seems that there is no such relationship between any audit opinion, the UMAO has not significantly differ from the MAO as well as U-EMP because the theory test that the $95 \%$ confidence level and the differences between each other is not equal to zero ( 0 ) it means there is no any significant difference between tested items. And also the MAO is not significantly differ from the U-EMP.

Table 03: Post Hoc Tests - Multiple Comparisons

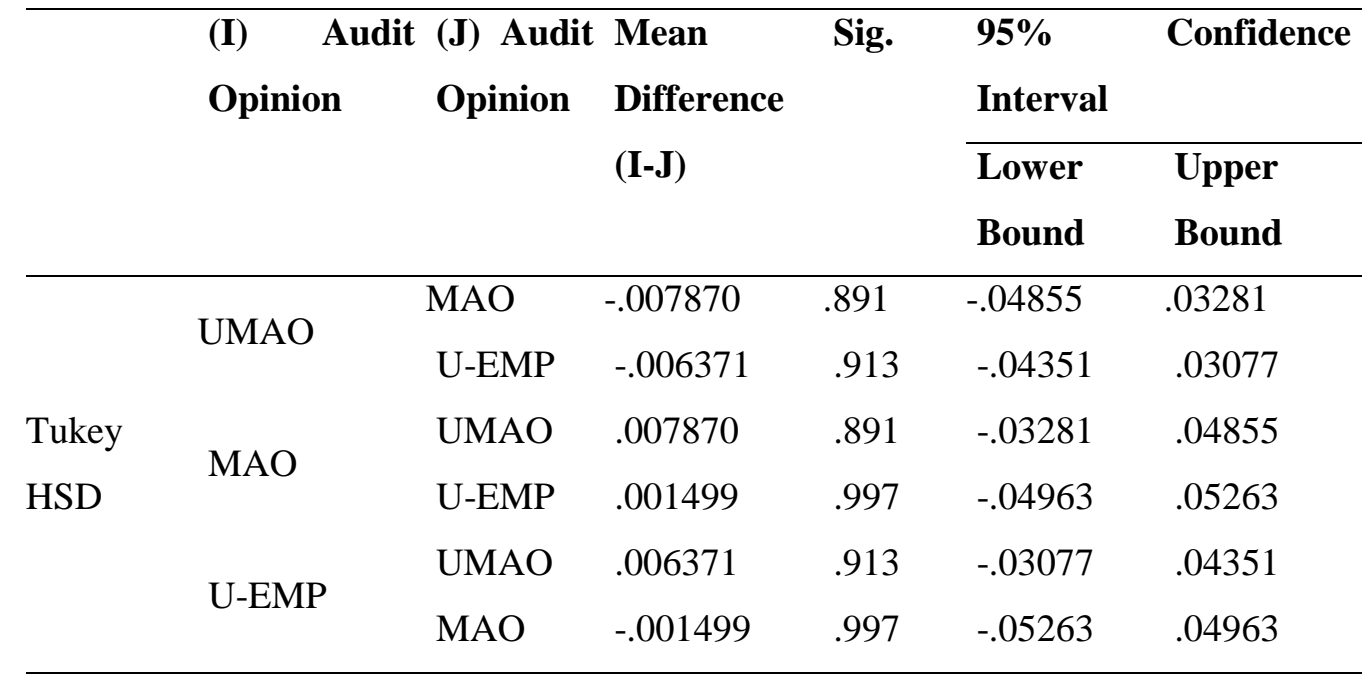

The mean differences testing significant level is 0.05

The table of multiple comparison displays the followings, and result are presented such kind of manner, UMAO vs. MAO that the calculated significant value is 0.891 ; that this is higher that the tested significant level of 0.05 ; thus this group does not differ. Moreover, UMAO vs. U-EMP that here the result of significant value is 0.913 , it is strongly more than tested significant level value of 0.05 ; therein these two groups have not differed from each other. Then, MAO vs. U-EMP can see the statistical amount such, the interpreted significant value is 
0.997, forcefully the value is higher than the tested significant level and therefore, it possibly interpret that there is no significant difference between MAO and UEMP too.

Thus, previously indicate that, therein derive the UMAOs have not any significant difference with other audit opinions as well as not any information content to the investors; as same the MAOs have not significant different between each other two audit opinions and likewise not appeared any information value to the investors, furthermore the U-EMPs also not significantly differ from each other audit opinions and reveal have not provide any information towards investors. As a whole result is the all audit opinions are not significantly different and as an entirely the all audit opinions haven't any significant relationship with capital gain yield, otherwise the all audit opinions are not present any information for investment decisions in Sri Lanka.

To all sense of this result, that there is no any significant difference between each audit opinion, but the prior literature supposed at least the U-EMP (concerning GC manner) also differ from other audit opinions. But it is not exhibit any strong differences on means of the each audit opinions. Therefore, it conceives the all audit opinions are same as their behavior and the CGY response similarly. The all evidence proves that under the limitations of the study, that there is

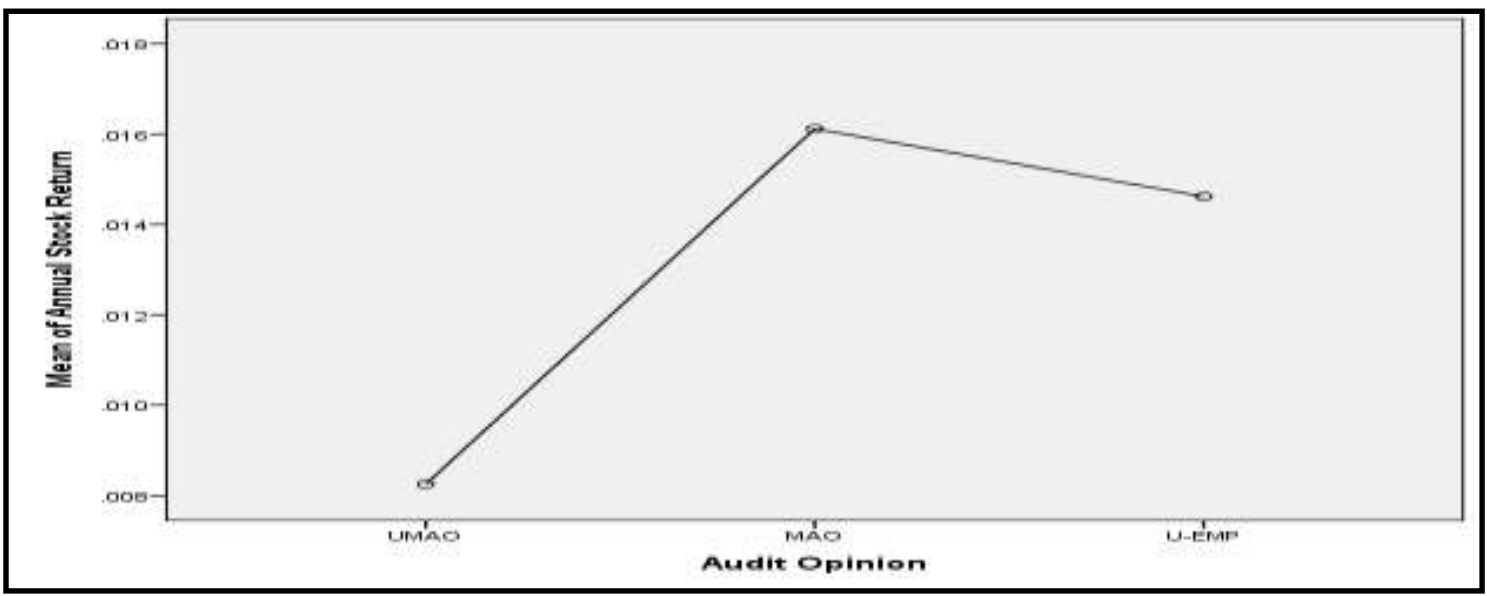


information content of all audit opinion is genuinely not displays; it is subjectively. However, that can be come to inspection as the presented result that the all audit opinions have not information content. Prove the evidence as this discloses previous figures, the figure 02 and 03 below explains the condition of the result manifestly.

\section{Figure 02: Means Plots}

This diagram depicts the degree of means plot at each audit opinion, here can see, that varies from each but when we consider the statistical value, this difference is not significant. It can be demonstrated by the refine this diagram; such kind of improved diagram illustrate below. Clarify the situation and result logically by the new diagram.

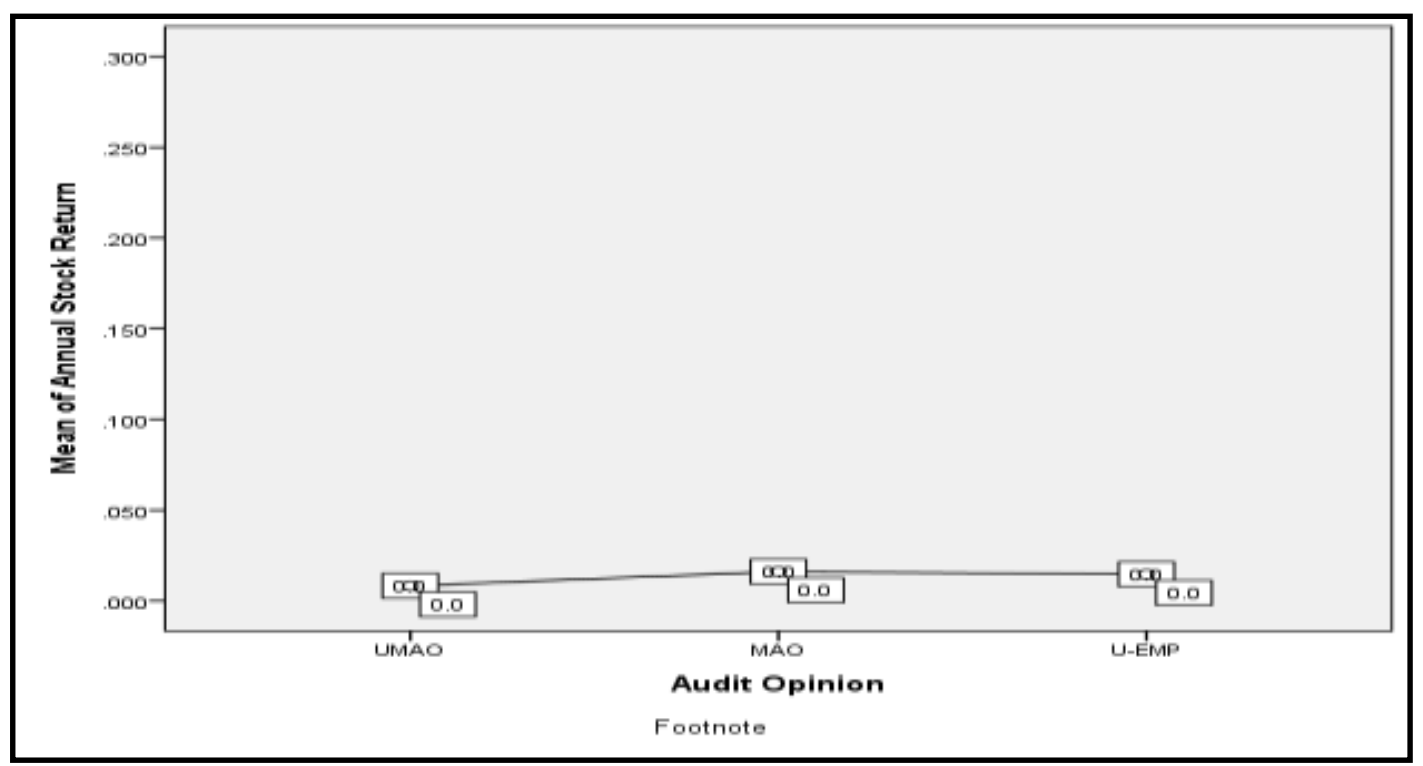

Figure 03: Refinement of the Means Plot

According to the means plot it also illustrates the same position on the relationship between audit opinions and capital gain yield. There is no significant relationship between each audit opinion and the capital gain yield. When compare the developed hypothesis and the entire results as the ANOVA table depicts figures 
and it expose result as well as the table of multiple comparisons' expressions the null hypotheses should be accept but the meaning is oppose to the derived result, hence it emerge the Type II error on the hypothesis testing that need to reject null hypothesis but cannot do it. It should need to clear understanding that according to the theory that express such kind of situation the null hypothesis is not true however it's impossible to reject the null hypothesis.

\section{Conclusion}

The investigation of "The External Auditor's Opinions and the Stakeholders' Purposes; An Empirical Analysis in Sri Lanka" has been proceeded with using Sri Lankan condition. Here, the research had used three audit opinions and stock market reaction (CGY) including the sample of 31 manufacturing companies listed on CSE. In accord with the all process of investigating it present the comprehensible result through the hypotheses testing.

The most of the literatures support for the relationship between audit opinion and the stock price return in positive manner, hence this investigation derived the hypotheses as them, however the result be opposite to the hypotheses. It robust the notion of the audit opinions are not information content for the investors' decisions and the main result has been arisen such the capital gain yield has not any influenced by the resistant of audit opinion, this conclusion has been applicable with the notion of the Elliott, (1982), Martínez† et al (2004), Frost (1991), Dopuch $\mathrm{N}$ et al, (1986), Al-Thuneibat et al, (2008), Czernkowski et al, (2010), Moradi et al, (2011) Mutchler, (1985) and also (Frost, 1991) that they expressed the idea with their final conclusion is the audit opinions has not any informative value having any inspection surround by the different audit opinions.

This research is forward the final result stood opposite with the limitations of the time, data collection limitations and the narrow scope selection for the 
investigation of the selected area, sample size is not great and especially methodology limitations. Therefore the above limitations has been interrupted the pure result. And so there are little brainchild for the further investigators, that they could be avoided this limitations as well as advance statistical testing can be used behalf of the fundamental and simple method.

This study supplements the new knowledge to the existing body of knowledge about the Sri Lankan situation regarding the auditing. Here discernible thing is that the investors' do not concern about the auditing. This all result finalized and show the conclusion that the Sri Lankan investors have less knowledge behind the auditing. The novel knowledge is the all audit opinions are promulgating in Sri Lanka is not influenced to the investors in Sri Lanka in order to make investment decisions. As a whole result of this study, comes into the negative perception of the audit opinions' informative value.

\section{References}

Al-Thuneibat, A. A., Khamees, B. A., \& Al-Fayoumi, N. A. " The effect of qualified auditors' opinions on share prices: evidence from Jordan." Managerial Auditing journal, 23(1), 2008: 84-101.

Banks, D. W., \& Kinney, W. R. "Loss contingency reports and stock prices: An empirical study." Journal of Accounting Research, 20(1), 240-254, 1982: 240-254.

Blay, A. D., Geiger, M. A. "Market expectations for first-time going-concern recipients." ournal of Accounting, Auditing \& Finance, 16(3, 2001: 209-226.

Carlson, S. J., Glezen, G. W., \& Benefield, M. E. "An investigation of investor reaction to the information content of a going concern audit report while controlling for concurrent financial statement disclosures." Quarterly Journal of Business and Economics, 1998: 25-39. 
Chen, C. J., Su, X., \& Zhao, R. "An Emerging Market's Reaction to Initial Modified Audit Opinions: Evidence from the Shanghai Stock Exchange*." Contemporary Accounting Research, 17(3), 2000: 429-455.

Chen, K. C., \& Church, B. K. "Going concern opinions and the market's reaction to bankruptcy filings." Accounting Review, 1996: 117-128.

Choi, S. K., \& Jeter, D. C. "The effects of qualified audit opinions on earnings response coefficients." Journal of Accounting and Economics, 15(2), 1992: 229-247.

Craswell, A. T. "Studies of the information content of qualified audit reports." Journal of Business Finance \& Accounting, 12(1), 1985: 93-115.

Czernkowski, R., Green, W., \& Wang, Y. "The value of audit qualifications in China." Managerial Auditing Journal, 25(5), 2010: 404-426.

Dileo, C. Reviewing the literature. Music Therapy Research: Quantitative and Qualitative Perspectives. . 1995.

Dodd, P., Dopuch, N., Holthausen, R., \& Leftwich, R. "Qualified audit opinions and stock prices: Information content, announcement dates, and concurrent disclosures." Journal of Accounting and Economics, 6(1), 1984: 3-38.

Dopuch, N., Holthausen, R. W., \& Leftwich, R. W. "Abnormal stock returns associated with media disclosures of 'subject to'qualified audit opinions." Journal of Accounting and Economics, 8(2), 1986: 93-117.

Dopuch, N., Holthausen, R. W., Leftwich, R. W. "Predicting audit qualifications with financial and market variables." Accounting Review, 1987: 431-454.

Elliott, J. A. " "Subject to" Audit Opinions and Abnormal Security Returns-Outcomes and Ambiguities." Journal of accounting research, 20(2), 1982: 617-638.

Feldmann, D., \& Read, W. J. "Going-concern audit opinions for bankrupt companiesimpact of credit rating." Managerial Auditing Journal, 28(4), 2013: 345-363. 
Firth, M. "A note on the impact of audit qualifications on lending and credit decisions." Journal of Banking \& Finance, 4(3), 1980: 257-267.

Firth, M. "Qualified audit reports: their impact on investment decisions." Accounting Review, 1978: 642-650.

Frost, C. A. "Loss contingency reports and stock prices: A replication and extension of Banks and Kinney." Journal of Accounting Research, 29(1), 1991: 157-169.

Gomez-Guillamon, A. D. " The usefulness of the audit report in investment and financing decisions." Managerial Auditing Journal, 18(6/7), 2003: 549-559.

Gravetter, F. J., \& Forzano, L. A. B. Research methods for the behavioral sciences. CengageBrain. com., 2011.

Gul, F. A. "Qualified audit reports, field dependence cognitive style, and their effects on decision making." Accounting \& Finance, 30(2), 1990: 15-27.

Herbohn, K., Ragunathan, V., \& Garsden, R. "41)The horse has bolted: revisiting the market reaction to going concern modifications of audit reports." Accounting \& Finance, 47(3), 2007: 473-493.

İrem NUHOĞLU, Deniz PARLAK. "The Perceptions of The Financial Stakeholders on The Classification Of The Auditor: An Experimental Cross-Cultural Survey." MÖDAV 2012/4, 2012: 19-41.

Joe, J. R. "Why press coverage of a client influences the audit opinion." Journal of Accounting Research, 41(1), 2003: 109-133.

Jones, F. L. "The information content of the auditor's going concern evaluation." Journal of Accounting and Public Policy, 15(1), 1996: 1-27.

Kausar A., Taffler R. J.and Tan C. "The Going-Concern Market Anomaly." Journal of Accounting Research, 47(1), 2009: 213-239. 
Kausar, A., Taffler, R., \& Tan, C. "Anomalous price reaction and differential stockholder response to going-concern audit opinions and withdrawals." Available at SSRN 889282, 2006.

Kausar, A., Taffler, R., \& Tan, C. "The impact of bankruptcy code on the value of the auditor's going-concern opinion to investors." Available at SSRN 873989, 2006.

Kelly A. S, Mohrweis C.L. "Bankers' and investors' perceptions of the auditor's role in financial statement reporting: the impact of SAS No. 58." Auditing: A Journal of Practice and Theory, 9(9), 1989: 87-97.

Lin, Z. J., Tang, Q., \& Xiao, J. " An experimental study of users' responses to qualified audit reports in China." Journal of International Accounting, Auditing and Taxation, 12(1), 2003: 1-22.

Lopez, T. J., Vandervelde, S. D., \& Wu, Y. J. "Investor perceptions of an auditor's adverse internal control opinion." Journal of Accounting and Public Policy,28(3), 2009: 231-250.

Martínez†, M. C. P., Martínez, A. V., \& Benau, M. A. G. "Reactions of the Spanish capital market to qualified audit reports." European Accounting Review, 13(4), 2004: 689711.

Menon, K., \& Schwartz, K. B. "An empirical investigation of audit qualification decisions in the presence of going concern uncertainties*." Contemporary Accounting Research, 3(2), 1987: 302-315.

Menon, K., \& Williams, D. D. "Investor reaction to going concern audit reports." The Accounting Review, 85(6), 2010: 2075-2105.

Moradi, M., Salehi, M., Rigi, M., \& Moeinizade, M. "The effect of qualified audit report on share prices and returns: Evidence of Iran." African Journal of Business Management, 5(8), 2011: 3354-3360. 
Mutchler, J. F. A. "A multivariate analysis of the auditor's going-concern opinion decision." Journal of Accounting Research, 23(2), 1985: 668-682.

Ogneva, M., \& Subramanyam, K. R. "Does the stock market underreact to going concern opinions? Evidence from the US and Australia." Journal of Accounting and Economics, 43(2), 2007: 439-452.

O'Reilly, D. M. "Do investors perceive the going-concern opinion as useful for pricing stocks?" Managerial Auditing Journal, 25(1), 2009: 4-16.

Palepu, K. G., \& Healy, P. M. Business analysis \& valuation: using financial statements. Mason, OH: Thomson/South-Western, 2008.

Power, M. The audit explosion (No. 7). Demos, 1994.

Roden, P. F., \& Meador, J. W. "An Analysis of the Audit Guide's Impact on the Sensitivity of Life Company Stocks." Journal of Risk and Insurance, 1980: 660-677.

Salehi, M., \& Bizhan, A. "Evaluating Effectiveness of External Auditors' Report: Empirical Evidence from Iran." Pakistan Journal of Commerce and Social Sciences, 4(1), 2010: 69-83.

Schaub, M. "Investor overreaction to going concern audit opinion announcements." Applied Financial Economics, 16(16), 2006: 1163-1170.

Shelton, S. W., \& Whittington, O. R. "The influence of the auditor's report on investors' evaluations after the Sarbanes-Oxley Act." Managerial Auditing Journal,23(2), 2008: 142-160.

Taffler, R. J., Lu, J., Kausar, A. "In denial? Stock market underreaction to going-concern audit report disclosures." Journal of Accounting and Economics, 38, 2004: 263296.

Whittred, G. P. "Audit qualification and the timeliness of corporate annual reports." Accounting Review, 1980: 563-577. 